\title{
Article
}

\section{Styles and Present Dimensions of Attachment in University Students}

\author{
Diego Santos ${ }^{1}$, Soledad Fierro² ${ }^{2}$, María Panchi ${ }^{3}$ and Enma Estrada ${ }^{4, *}$ \\ 1 School of Psychology, Universidad Nacional de Chimborazo, Riobamba 060150, Ecuador. \\ 2 School of Psychology, Universidad Nacional de Chimborazo, Riobamba 060150, Ecuador. \\ * Correspondence: dsantos@unach.edu.ec ; Te.: +593-9-9664-7577
}

\begin{abstract}
The objective of the present study is to evaluate and analyze styles and dimensions of attachment, its possible relations and how they become evident in the people involved in this study, For accomplishing it, a quantitative focus methodology was applied of descriptive type and crosscut, in which 105 Clinical Psychology university career students participated. The CaMir-R questionnaire was applied to evaluate the different styles and dimensions of attachment. In regard to the main found results it can be mentioned that - as much in men as in women -. the disorganized attachment is the most representative, followed by safe attachment. In turn, there exists a significant difference established by gender in these dimensions: family worry, parental permissiveness and infantile traumatism; In addition, as much positive correlations like refusals ones among the renowned dimensions were observed, where bulges out the positive link of self-sufficiency and resentment against the parents with the infantile traumatism. It came to an end that the dependence between the type of relation and the predisposal of offering a sure attachment on behalf of the progenitor, it will generate in the person an atmosphere of satisfaction and a capacity to face the penalties of life everyday.
\end{abstract}

Keywords: styles; dimensions; attachment; students

\section{Introduction}

One of the more spread-out theoretic perspectives within the psychology which tries to explain close relationships, is the theory of the attachment of Bolwly (1) and one of the stages in which these relations become evident in is the university one. From there the interest of the present work that focuses on analyzing the styles, the dimensions of attachment of this age group and what is the relational dynamics among these. The main motivation for accomplishing this research has support in problems found in students of the first and second semesters of the Clinical Psychology career, where, in some cases, they present difficulties in the interpersonal relations with their parents due to the scarce communication and affectional bond permanent. In turn, with their companions, provides evidence of his identity problems of integration to the group, lack of assertiveness, little recognition and expression of feelings, reasons for which junior university student experiences complex situations at psychological level that affect his personal and academic development inherent to each student. Therefore, the present studys intends to know style and dimension of inherent attachment to each student, with the objective to establish viable strategies to improve psychosocial performance, that it is been beneficial to decrease the student desertion as well.

In an investigation accomplished in Chile, where the relations between the styles of attachment and the difficulties in the emotional involvement of university students were evaluated, it provided evidence that a significant part of the population presents sure attachment and takes over its emotions, unlike the subjects that reflect the insecure 
attachment that they do not control them; on the other hand, it became also evident that high scores in the worried attachment that represents the emotional rejection and social interference. ${ }^{(2)}$

Bolwly -in the attachment theory- defines that the behavioral characteristics that the people possess from their birth in the search of safety and protection depends not only on its progenitors, but also on the people that are under their care, according Morán, J y Martínez. (3) It is then understood how attachment contributes to the survival of the person, because care figure offers securitty and combat to the problematical conditions that generate insecurity. (4) Therefore, when creating a link, the subject will have opportunity to carry out an adequate social and emotional development. (5)

The figures of attachment in the course of the development of a human being take a connotation of its own in each subject, for which this phenomenon not only directs to his parent's relations, but also to relations with friends, couples, among others that get up date during one's lifetime, motivated for new experiences. ${ }^{(6)}$ The links that day by day are generated with the figure of attachment step by step strengthen the self-concept and the social perception of the subject. This generates a singularity in the development of personality and the infant's emotional abilities (7), in such a way that it is useful to the individual in order to be able to be identified in the society as a unique being and that way to look for certainty in his relations. ${ }^{(8)}$

There are four attachment styles: Secure, avoidable, worried and disorganized (9), characteristics that are not based on relations only, but also in internal operating models that help to interpret, to direct and to have influence in the different emotions and actions. (10)

In so far, the attachment dimensions, Laccase and Muela (11) point out that certainty, availability and support of the attachment figures relate to each other in positive way with secure attachment, that is characterized for the confidence to express feelings, and of negative way with the insecure attachment, that manifests itself for the emotional rejection. In turn, the familiar worry indicates the fear that the person shows for the separation of the members of the family; the parental interference also focuses on the fear to be abandoned and overprotected in infancy. In addition, self-sufficiency and resentment against the parents refer the rejection for the mutual feelings and the resentment toward the figures of attachment. The infantile traumatism suggests the experiences of violence or threat provided by the progenitors since early childhood. Finally, the value of authority and the parental permissiveness comprise to the dynamics and family structure of the subject.

\section{Materials and Methods}

The study was carried out by means of a quantitative focus, of descriptive type and transversal; its intention was to identify dimensions and styles of attachment, with a not probabilistic sampling for convenience, shaped for 105 university students of first and second semester of the Clinical Psychology career.

With the aim of evaluating attachment the CaMir R ${ }^{(12)}$ was used. It consists of 32 items with five response options. It reflects seven dimensions; among them it was found 1) Security, availability and support of attachment figures. 2) Familiar worry. 3) Parental interference. 4) value of the parental authority. 5) Parental permissiveness. 6) Self-sufficiency and resentment toward the parents, and 7) Infantile traumatism. The first dimension will reflect an secure attachment; the second and third class refer the worried attachment. The fourth and fifth correspond to the family structure representations; the sixth one to the avoidable attachment, and finally the seventh to the disorganized attachment.

Based on the analysis of the evaluation of the attachment accomplished with university students of Peru in 2012, it could be identitied that the seven attachment dimensions 
that correspond to CaMir-R questionnaire present an internal consistency of 0,85 , for which there exist high values of reliability for the application of the instrument. (13)

For the data processing the statistical package IBM SPSS version 24 was used, taking into account descriptive statisticians, proofs of normality and correlations applied to the corresponding attachment variables.

\section{Results}

Table 1. Attachment style according to gender

\begin{tabular}{cllc}
\hline Gender & Attachment & Frecuency & Percentage \\
\hline \multirow{4}{*}{ Male } & Secure & 12 & 37,5 \\
\cline { 2 - 4 } & Worried & 2 & 6,3 \\
\cline { 2 - 4 } & Avoidable & 3 & 9,4 \\
\cline { 2 - 4 } & Desorganized & 15 & 46,9 \\
\cline { 2 - 4 } & Total & $\mathbf{3 2}$ & $\mathbf{1 0 0}$ \\
\hline \multirow{5}{*}{ Female } & Secure & 30 & 41,1 \\
\cline { 2 - 4 } & Worried & 5 & 6,8 \\
\cline { 2 - 4 } & Avoidable & 1 & 1,4 \\
\cline { 2 - 4 } & Desorganized & 37 & 50,7 \\
\cline { 2 - 4 } & Total & $\mathbf{7 3}$ & $\mathbf{1 0 0}$ \\
\hline
\end{tabular}

In the present table the styles of attachment regarding the kind of every student can be observed. Its identities that in men the Disorganized Attachment (46.9\%) is more representative, followed by the Secure, (37.5), the Avoidable and the Worried with an inferior percentage (9.4\%) (6.3\%), respectively. In addition, women present high percentages in the Disorganized Attachment (46.9\%), followed by the Secure (41,1 \%) and low percentages in the Worried and Avoidable ones.

Table 2. Comparison for groups of the dimensions of attachment

\begin{tabular}{|c|c|c|c|c|c|c|}
\hline Dimensions of Attachment & Gender & $\mathbf{N}$ & Mean & $\begin{array}{l}\text { Standard } \\
\text { Deviation }\end{array}$ & $\begin{array}{c}\text { Standard Mean } \\
\text { Error }\end{array}$ & p \\
\hline Security: Availability and & Male & 32 & 26,813 & 3,2965 &, 5827 & \\
\hline $\begin{array}{l}\text { support of the figures of } \\
\text { attachment }\end{array}$ & Female & 73 & 27,055 & 4,3394 &, 5079 & 0,775 \\
\hline \multirow{2}{*}{ Familiar Worry } & Male & 32 & 18,313 & 3,8641 & 6831 & \multirow{2}{*}{$<0,05$} \\
\hline & Female & 73 & 22,151 & 4,1455 & 4852 & \\
\hline \multirow{2}{*}{ Parents Interference } & Male & 32 & 12,969 & 2,4820 & ,4388 & \multirow{2}{*}{0.978} \\
\hline & Female & 73 & 12,986 & 3,1024 & 3631 & \\
\hline \multirow{2}{*}{ Value of the parental authority } & Male & 32 & 13,250 & 1,6656 & ,2944 & \multirow{2}{*}{0.594} \\
\hline & Female & 73 & 13,452 & 2,0141 & ,2357 & \\
\hline \multirow{2}{*}{ Parental Permisivity } & Male & 32 & 7,844 & 2,0018 & ,3539 & \multirow{2}{*}{$<0,05$} \\
\hline & Female & 73 & 6,767 & 1,9616 & ,2296 & \\
\hline \multirow{2}{*}{$\begin{array}{l}\text { Self-sufficiency and Rencor } \\
\text { against the parents }\end{array}$} & Male & 32 & 12,500 & 2,9512 &, 5217 & \multirow{2}{*}{0.607} \\
\hline & Female & 73 & 12,822 & 2,8980 & ,3392 & \\
\hline \multirow{2}{*}{ Infantile traumatism } & Male & 32 & 12,625 & 4,1872 & ,7402 & \multirow{2}{*}{$<0,05$} \\
\hline & Female & 73 & 14,014 & 4,2898 & ,5021 & \\
\hline
\end{tabular}


As provides evidence of its identity in the Table 2, the familiar worry, parental permissiveness and infantile traumatism show up dissimilar in shape between men and women $(<0.05)$, while in the other dimensions comparatively significant differences related in these two groups. were not found.

Table 3. Relation among the dimensions of attachment

\begin{tabular}{|c|c|c|c|c|c|c|c|}
\hline & 1 & 2 & 3 & 4 & 5 & 6 & 7 \\
\hline 1 & $\begin{array}{l}\text { Security: } \\
\text { Availability and } \\
\text { support of the } \\
\text { figures of } \\
\text { attachment }\end{array}$ &, $223^{*}$ &,- 104 &, $340^{* *}$ &,$- 253^{* *}$ &,$- 476^{* *}$ &,$- 414^{* *}$ \\
\hline 2 & Familiar Worry & &, $357^{* *}$ &, $218^{*}$ &,- 111 & ,183 & ,176 \\
\hline 3 & $\begin{array}{l}\text { Parents } \\
\text { Interference }\end{array}$ & & & ,003 & ,035 &, $375^{* *}$ & $253^{* *}$ \\
\hline 4 & $\begin{array}{l}\text { Value of the } \\
\text { parental } \\
\text { authority }\end{array}$ & & & &,$- 218^{*}$ &,- 019 &,$- 234^{*}$ \\
\hline 5 & $\begin{array}{l}\text { Parental } \\
\text { Permisivity } \\
\end{array}$ & & & & & ,134 & ,166 \\
\hline 6 & \begin{tabular}{lr}
\multicolumn{2}{l}{ Self-sufficiency } \\
and & Rencor \\
against & the \\
parents & \\
\end{tabular} & & & & & &, $611^{* *}$ \\
\hline 7 & $\begin{array}{l}\text { Infantile } \\
\text { traumatism }\end{array}$ & & & & & & \\
\hline
\end{tabular}

In the table it can be identified as much positive relationships as negative ones among the corresponding dimensions to attachment. In regard to the positive prints, it was found that Securiry: Availability and Support of the Figures of Attachment relate with Familiar Worry $(r=, 223 p<, 005)$, and the Value of the Parental Authority $(\mathrm{r}=, 340 p<, 001)$. Familiar Worry relates with Parental Interference ( $r=, 357 p<, 001$, and the Value of the Parental Authority $(\mathrm{r}=, 218 p<, 005)$. The Parental Interference relates with Self-Sufficiency and Resentment Against the Parents $(r=, 375 p<, 001)$ and with Infantile Traumatismo (r=, $253 p<, 001)$, finally Self-Sufficiency and Resentment Against the Parents relates with the Infantile Traumatism ( $\mathrm{r}=, 611 p<, 001)$. In addition, in the negatives it was found that Security: Availability and Support of the Figures of Attachment relates with Parental Permissiveness $(r=-, 253 p<, 001)$, in turn with Self-Sufficiency and Resentment Against the Parents $(\mathrm{r}=-, 476 p<, 001)$ and with the Infantile Traumatism ( $\mathrm{r}=-414 p<$, 001). The Value of the Parental Authority relates with the Parental Permissiveness $(r=-, 218 p<, 005)$ and with the Infantile Traumatism $(\mathrm{r}=-, 234 p=, 005)$.

\section{Discussion}

In the studied context, the attachment style that had greater presence was the disorganized attachment as much in women as in men with a percentage of the $50.7 \%$ was and $46.9 \%$ respectively, just like Lastra and collaborators mention ${ }^{(14)}$ in their study, where it is observed that $46.60 \%$ of women and $39.48 \%$ of the men denote a Secure Attachment, in turn it is necessary to indicate that there exist important Disorganized Attachment values in men, with the $37.5 \%$ and women, with the $41.1 \%$, unlike what Santelices ${ }^{(15)}$ and collaborators propose, those who found out that Secure Attachment is the most representative in the covered population with a $53.3 \%$. 
In the comparative analysis of gender means it was found that there exit significant differences in men and women regarding dimensions Familiar Worry, Parental Permissiveness and Infantile Traumatism, unlike what García and Soriano ${ }^{(16)}$ expose where significant differences related with the theme are not found.

In regards to the study of correlation between the variables it gives the appearance of being the existence of an important negative relationship among the certainty that the Figures of Attachment with the Parental Permissiveness, Self-Sufficiency and Resentment Against the Parents, and Infantile Traumatism provide, meanwhile, positive way with Familiar Worry and Value of the Parental Authority, data that are similar to those exposed by Ching and Tak (17), in which Securiry, Availability and Support of the Figures of Attachment relates with Familiar Worry $(\mathrm{r}=-, 389 p<, 001)$; Parents Interference $(\mathrm{r}=-, 389 p<$, 001, Sself-Sufficiency and Resentment Against the Parents ( $\mathrm{r}=-, 450 p<, 001)$; and positively with Infantile Traumatism $(r=, 152 p<$, 005). Similarly, when analyzing the investigation proposed by Passanisi ${ }^{(18)}$ it has been found that dimension Security links up with SelfSufficiency and Resentment Against the Parents ( $r=-, 33 p<, 001)$.

In turn, it has been found that Self-Sufficiency and Resentment Against the Parents relates with the Infantile Traumatism in the students, aspects similarly observed in thew Ching and Tak ${ }^{(17)}$ research, where such a dimensión vinculates with Traumatism ( $r=.207$ $p<, 001)$. Finally, Passanisi ${ }^{(18)}$ shows different data to those exposed where Self-Sufficiency and Resentment Against the Parents relates in a positive way with Familiar Worry $(\mathrm{r}=, 45$ $p<, 001)$..

\section{Conclusions}

In the students carried out this research prevails the disorganized attachment which is characterized by the infantile shock that the progenitor caused by a practice of aggressive and violent get-together. In turn it cannot be left aside the Security Attachment that is also in an important way in the population.

The dimensions of the attachment with bigger difference among men and women are: Relatives Worry, Parental Permissiveness and Infantile Traumatism, factors that will leave a mark an influence for the subject to develop in a determined way in their everyday life.

As much positive like negative authenticated correlations among the different dimensions concerning to attachment; in special way can be mentioned meanwhile there exists more security provided by the backup figures, the Resentment Against the Parents and the Infantile Traumatism will diminish.

Author Contributions: Form analysis, D.S.- p.; Investigation, M.P.- S, E.E.- Ch.; Supervision, S.F.V. All the authors worked on the fact-finding process and in the wording of the article. All the authors have read and accepted the manuscript published version.

Funding: This investigation did not receive outside financing.

Institutional Review Board Statement: The ethical considerations that were considerate are based on the respective authorizations formulated by the authorities that lead the Clinical Psychology Career, respecting the voluntary of participation in the process. The confidentiality rules were implemented to keep the data obtained, the veracity with the application of informed consent to the students and the principles of beneficence, autonomy and justice. At the time of the evaluation, the participants did not present obvious psychosocial difficulties, therefore they are not considered vulnerable.

Informed Consent Statement: Informed consent was obtained from all subjects involved in the study. 
Acknowledgments: We are grateful to the Clinical Psychology Career of Universidad Nacional de Chimborazo, Ecuador for the given support. To the all-comers to agree voluntarily to be case-study part and to sign the respective informed consent.

Conflicts of Interest: Authors declare themselves not to have any conflicts of interests.

\section{References}

1. Bowlby J. Vínculos afectivos: formación, desarrollo y pérdida. Madrid, España: Morata. 1979.

2. Guzmán-González M, Carrasco N, Figueroa P, Trabucco C, Vilca D. Estilos de apego y dificultades de regulación emocional en estudiantes universitarios. Psykhe. 2016;25(1):1-13.

3. Morán J, Martínez C. El apego en la adolescencia: una revisión sistemática de la investigación latinoamericana durante los últimos 15 años. Rev Argentina Clin Psicol. 2019;28(2):172-82.

4. Tay Karapas K, Guzmán González M, Barrera Silva J, Lovys Tirado D, Olmos Córdova A. Propiedades psicométricas de la escala de experiencias en relaciones cercanas-estructuras de relaciones (ECR-RS) para medir apego en adolescentes chilenos. Salud Soc. 2015;6(1):78-93.

5. Solórzano Ramirez Y, Berrocal Chirinos B, Vilca Quiro W. Estilos de apego y conductas autodestructivas en agentes en actividad de la Policía Nacional del Perú de Lima. Rev Científica Ciencias la Salud. 2018;10(2).

6. Matos P. Estilos de apego en la relación de pareja y niveles del bienestar psicológico en estudiantes universitarios de una universidad privada de Lima. 2017;1-25. Available from: http://repositorio.urp.edu.pe/bitstream/handle/urp/1135/Patricia Matos $\% 282017 \% 29$ Estilos de apego y niveles de ansiedad.pdf?sequence=1\&isAllowed=y

7. Medina CJ, Rivera LY, Aguasvivas JA. El apego adulto y la calidad percibida de las relaciones de pareja: Evidencias a partir de una población adulta joven. Salud Soc. 2017;7(3):306-18.

8. García S, Gutiérrez G, Martínez N. Prevención en la relación de apego entre las madres adolescentes y sus hijos en la infancia temprana. 2016;2(3):30-5.

9. Rojas T. El apego como uno de los elementos fundamentales en el funcionamiento psíquico de víctimas reincidentes. Revista Electrónica de Psicología Iztacala. [Internet] 2020. 23(1),418-438.

10. Benlloch Bueno S. Teoría del Apego en la Práctica Clínica. Rev Psicoter. 2020;31(116):169-89.

11. Lacasa F, Muela A. Guía para la aplicación e interpretación del cuestionario de apego CaMir-R. Rev Psicopatología y Salud Ment del Niño y del Adolesc. 2014;24:83-93.

12. Balluerka N, Lacasa F, Gorostiaga A, Muela A, Pierrehumbert B. Versión reducida del cuestionario CaMir (CaMir-R) para la evaluación del apego. Psicothema. 2011;23(3):486-94.

13. Gómez E. Evaluación del apego en estudiantes universitarios. Horiz Med (Barcelona). 2012;12(3):42-6.

14. Lastra H, Yessica U. Estilos de apego emocional y satisfacción marital en los padres de familia del distrito de Huachón de Pasco, 2016. Resolucion [Internet]. 2016;1:6374. Available from: https://repositorio.upeu.edu.pe/bitstream/handle/UPEU/716/Hernan_Tesis_bachiller_2017.pdf?sequence=1\&isAllowed=y

15. Santelices M, Guzmán M, Garrido L. Apego y Psicopatología : Estudio comparativo de los estilos de apego en adultos con y sin. 2011;XX:49-55.

16. García H, Siriano E. "Amigos con beneficios": Salud sexual y estilos de apego de hombres y mujeres. Saude e Soc. 2016;25(4):1136-47.

17. Ching K, Tak L. The Structural Model in Parenting Style, Attachment Style, Self-regulation and Self-esteem for Smartphone Addiction. IAFOR J Psychol Behav Sci. 2017;3(1):85-103.

18. Passanisi A, Gervasi AM, Madonia C, Guzzo G, Greco D. Attachment, Self-Esteem and Shame in Emerging Adulthood. Procedia - Soc Behav Sci [Internet]. 2015;191:342-6. Available from: http://dx.doi.org/10.1016/j.sbspro.2015.04.552 